УДК 346.1

DOI https://doi.org/10.32849/2663-5313/2020.2.20

Катерина Харківська,

канд. юрид. наук, помічник судді

Господарсъкого суду Харківсъкої області

\title{
ОСНОВНІ НАПРЯМИ ЗДІЙСНЕННЯ ДЕРЖАВНОГО РЕГУЛЮВАННЯ ВИРОБНИЧОЇ ДІЯЛЬНОСТІ В УКРАЇНІ
}

У статті досліджено особливості державного впливу на виробничу діяльність, розглянуто його сутність та форми. Визначено, що головним і невід’ємним інструментом регулюючого впливу держави на виробничу діяльність виступає господарське право. Його роль $і$ значення під час здійснення підприємницької діяльності складно перебільшити, а питання, які пов'язані із правовим забезпеченням виробничої діяльності, були і залишаються актуальними. Досліджено основні форми регулюючого впливу держави на виробничу діяльність суб'єктів підприємниитва. Встановлено, що регулюючий вплив держави на виробничу діяльність суб'єктів підприємництва, не обмежується лише підтримкою. У роботі також розглянуто різні підходи науковиів до диферениіації засобів регулюючого впливу держави на виробничу діяльність. На підставі аналізу нормативно-правових актів щодо здійснення державного регулювання виробничої діяльності виділено основні чинники, які впливають на виробничу діяльність суб'єктів підприємництва. Звернуто увагу на напрям державного регулювання виробничої діяльності, який стосується державної політики у сфері розвитку економічної конкурениї та обмеження монополізму в господарській діяльності. 3'ясовано, що окремі види регулюючого впливу держави виконують функиію обмеження свободи виробничої діяльності суб'єктів підприємництва, зокрема ліцензування, технічне регулювання, иіноутворення тощо. Проте інші, як-от дотацї, компенсацї, податкові та митні пільги, є такими, що підтримують свободу підприємничтва. Визначено, що одним із головних завдань держави на сучасному етапі є ефективний регулюючий вплив держави на виробничу діяльність суб'єктів підприємниитва. А ї̈ реалізаиія вимагає иілісної кониепиї щодо галузевої правової приналежності підприємницьких відносин, тобто їхнього місия в системі права і законодавства, оптимально допустимих меж втручання держави у сферу регулювання виробничої діяльності підприємницьких відносин, а також юридичних гарантій підприємництва і відповідальності в цій сфері. У роботі також виокремлено основні напрями державного впливу на виробничу діяльність.

Ключові слова: виробнича діяльність, державне регулювання, комерційне господарювання, суб’єкти підприємницької діяльності, засоби державного регулювання господарської діяльності.

Постановка проблеми. Сьогодні, коли перебіг економічних реформ у державі не можна назвати успішним, наука перебуває на новому витку пошуків, відшукування області ефективного функціонування та взаємозв'язку держави, права та підприємництва, тому зазначені питання набувають особливої значущості як на теоретичному, так і на практичному рівнях.

Метою статті є виявлення особливостей державного впливу на здійснення виробничої діяльності суб'єктів підприємництва.

Виклад основного матеріалу. Існують різноманітні форми регулюючого впливу держави на виробничу діяльність суб'єктів підприємництва. Безпосереднє державне управління низкою галузей, об'єктів цілком або частково застосовується до підприємств, організацій, які життєво важливі для еконо- міки і суспільства, що потребують значної державної підтримки. До таких об'єктів відносять військові, оборонні, енергетичні, заповідники, національні музеї, природні парки, курорти, корисні копалини, водні ресурси, низку установ науки, культури, освіти, охорони здоров'я. По-перше, це може бути податкове регулювання, що здійснюється шляхом встановлення тих чи інших об'єктів оподаткування, призначення та диференціації податкових ставок, уведення податкових пільг, звільнення від податків. У тому ж напрямі впливає і введення мит, митних зборів. Зрозуміло, що зміною в той чи інший бік податкового тягаря держава може прискорювати або сповільнювати виробничі процеси. Водночас стягування податків - головне джерело доходів державного бюджету, фінансова база соціальної політики. Цінове регулювання в умовах ринкової економіки поля- 
гає в тому, що держава може встановлювати граничний рівень цін на продукцію суб'єктів підприємництва. Грунтуючись на зазначених принципах і умовах здійснення підприємницької діяльності, суб'єкт підприємництва самостійно визначає напрями виробничої діяльності, ïi структуру й обсяг, самостійно розпоряджається виробленою продукцією та доходами, здійснює будь-яку діяльність що не суперечить законодавству України.

За характером впливу на виробничу діяльність суб'єктів підприємницької діяльності засоби регулюючого впливу поділяються на дві форми: прямі та непрямі. У свою чергу, прямі засоби впливають на виробничу діяльність безпосереднім використанням відповідних регуляторів, а саме: через бюджетне інвестування державою відповідних програм фінансування розвитку суб'єктів підприємницької діяльності державного сектора економіки, інфраструктури, науки, культури, освіти, соціального захисту населення тощо, а також через регламентацію цін, заробітної плати й інших інструментів ринкового механізму. Зазначений прямий вплив зазвичай полягає у використанні адміністративних важелів, які регламентують конкретні завдання й обмеження підприємницької діяльності, обмежуючи тим самим свободу підприємницької діяльності. Але ці обмеження, на нашу думку, є позитивними.

Непрямий вплив на виробничу діяльність суб'єктів підприємництва відбувається шляхом внесення відповідних змін в умови функціонування ринкового механізму, що досягається за допомогою правових і економічних інструментів. Застосовуючи ці інструменти, держава безпосередньо нічого не змінює в ринковому механізмі, а створює лише передумови для цих змін.

Крім того, серед основних засобів регулюючого впливу держави на виробничу діяльність суб'єктів підприємництва варто виокремити: 1) законодавчі акти; 2) прогнози розвитку національної економіки; 3) концептуальні та програмні документи; 4) ліміти; 5) державні замовлення і контракти; 6) ліцензування видів господарської діяльності; 7) встановлення квот; 8) державні інвестиції; 9) державні та місцеві бюджети; 10) бюджетні дотації, субсидії, субвенції; податки і податкові пільги, державні кредити; 11) державні резерви; 12) операції з державними цінними паперами на відкритому ринку; 13) соціально-економічні нормативи; 14) галузеві та загальнодержавні норми, стандарти; 15) норми амортизації, зокрема прискореної; 16) встановлення граничних рівнів рентабельності; 17) систему фіксованих, граничних і вільних цін;
18) індексування цін тощо. Наявні різні підходи науковців до цього питання.

Так, Н.О. Саніахметова до засобів державного регулювання підприємництва відносить: 1) аудит діяльності підприємців; 2) бухгалтерський облік і звітність; 3) державну реєстрацію суб'єктів підприємництва; 4) квотування зовнішньоекономічної діяльності; 5) контроль за ціноутворенням і цінами; 6) ліцензування деяких видів підприємництва; 7) ліцензування зовнішньоекономічної діяльності; 8) митно-тарифні засоби; 9) недопущення недобросовісної конкуренції; 10) облік (реєстрація) зовнішньоекономічних договорів; 11) оподаткування; 12) обмеження монополізму; 13) обмеження окремих видів реклами; 14) патентування окремих видів підприємницької діяльності; 15) стандартизацію та сертифікацію продукції і послуг [1, с. 69]. А, наприклад, О.В. Покатаєва до основних засобів, які використовує держава для регулювання підприємницької діяльності, відносить: державну реєстрацію; ліцензування, патентування, квотування; сертифікацію та стандартизацію; регулювання цін і тарифів; податкове регулювання (надання податкових пільг); надання дотацій, компенсацій; застосування нормативів і лімітів; матеріально-технічну підтримку підприємців: інформаційне, кадрове та науково-методичне забезпечення підприємців [2, с. 90].

Здійснення державного регулювання виробничої діяльності забезпечується цілим комплексом нормативно-правових актів, серед них такі: закони України «Про ліцензування видів господарської діяльності» [3], «Про ціни і ціноутворення» [4], «Про стандартизацію» [5], «Про зовнішньоекономічну діяльність» [6], «Про захист економічної конкуренції» [7] тощо. Тобто до засобів регулюючого впливу держави на виробничу діяльність суб'єктів підприємництва варто віднести такі спеціальні засоби й інструменти регулювання: 1) норми, нормативи, наприклад, мінімальний розмір встановленого капіталу господарського товариства, нормативи достатності власних коштів у ліцензіата - професійного учасника ринку цінних паперів, нормативи гранично допустимих шкідливих речовин у продуктах харчування, нормативи гранично допустимого рівня шуму, вібрації та інших шкідливих впливів на здоров'я людей у виробничих умовах; 2) ліміти, наприклад, ліміти на викиди забруднюючих речовин у природне середовище; 3) розміри ставок податків, мит тощо; 3) коефіцієнти, що застосовують під час державного регулювання цін і тарифів; 4) квоти - кількісні обмеження, наприклад 
на експорт або імпорт окремих видів товарів; 5) резерви та гранично допустимі суми, наприклад, у разі підвищення цін, під час розрахунків готівкою між юридичними особами, інші кількісні обмежувачі і вимоги. T.M. Кравцова зауважує, що, виконуючи функції державного регулювання економіки, державні органи та їх посадові особи повинні використовувати лише ті форми регуляторної діяльності, які встановлені правовими нормами [8, с. 46].

Також необхідно звернути увагу ще на один напрям державного регулювання виробничої діяльності, який стосується державної політики у сфері розвитку економічної конкуренції й обмеження монополізму в господарській діяльності. Так, суб'єкти господарювання, органи влади, органи місцевого самоврядування, а також органи адміністративно-господарського управління та контролю зобов'язані сприяти розвитку конкуренції та не вчиняти будь-яких неправомірних дій, які можуть негативно вплинути на конкуренцію [7]

Однак регулюючий вплив держави на виробничу діяльність суб'єктів підприємництва не обмежується лише підтримкою. Навпаки, підстави для державного втручання у виробничу діяльність лежать переважно у сфері публічних інтересів. Ступінь регулюючого впливу держави та його межі в разі втручання у справи суб'єкта підприємницької діяльності визначаються необхідністю і достатністю збереження істотних елементів ринкового регулювання економіки в поєднанні 3 коригуванням економічного розвитку в потрібному суспільству напрямі. Ці межі повинні бути точно намічені і закріплені в нормах господарського права. Фахівці в області підприємницького права зазначають, що регулюючий вплив держави на діяльність суб'єктів підприємництва може бути як прямим, так і непрямим.

До методів прямого (адміністративного) державного впливу належать: визначення стратегічних цілей розвитку економіки, їх вираження в індикативних та інших планах; державні замовлення і контракти на постачання окремих видів продукції; нормативні вимоги до якості та сертифікації технології та продукції; правові й адміністративні обмеження і заборони з випуску окремих видів продукції тощо. Методами непрямого регулювання виробничих процесів є: оподаткування; система податкових та митних пільг; ставки за кредит і кредитні пільги.

Державне прогнозування і планування розвитку виробничої діяльності суб'єктів підприємництва взагалі та підприємницької діяльності зокрема є одним із найважливі- ших непрямих засобів державного регулювання господарської діяльності. Державне прогнозування являє собою систему науково обгрунтованих уявлень про напрями соціально-економічного розвитку держави, заснованих на законах ринкового господарювання. Правовою основою здійснення державного планування і прогнозування є Закон України «Про державні цільові програми» [9], згідно з яким (ст. 1) Державна цільова програма - це комплекс взаємопов'язаних завдань і заходів, які спрямовані на розв'язання найважливіших проблем розвитку держави, окремих галузей економіки або адміністративно-територіальних одиниць, здійснюються з використанням коштів державного бюджету України й узгоджені за строками виконання, складом виконавців, ресурсним забезпеченням. У свою чергу, Закон України «Про державне прогнозування та розроблення програм економічного і соціального розвитку України» (ст. 1) [10] визначає державне прогнозування економічного і соціального розвитку як науково обгрунтоване передбачення напрямів розвитку країни, окремих галузей економіки або окремих адміністративно-територіальних одиниць, можливого стану економіки та соціальної сфери в майбутньому, а також альтернативних шляхів і строків досягнення параметрів економічного і соціального розвитку.

Також прикладом регулюючого впливу держави на діяльність суб'єктів підприємницької діяльності є Закон України «Про Національну програму сприяння розвитку малого підприємництва в Україні» [11], де регламентовано, що шляхами вдосконалення правового забезпечення розвитку малого підприємництва $€:$ 1) створення дієвих механізмів захисту прав і свобод підприємців; 2) гармонізація українського законодавства із законодавством Свропейського Союзу та Співдружності Незалежних Держав; 3) забезпечення законодавчої гарантії незмінності та довготривалості державної політики щодо підтримки малого підприємництва; 4) розроблення нормативно-правової бази, яка регулює відносини між державою та підприємцями, роботодавцями i найманими працівниками, зокрема і для забезпечення їх соціального захисту, встановлює норми і правила здійснення підприємницької діяльності, регламентує діяльність органів державної влади, їх посадових осіб щодо виконання ними відповідних повноважень у сфері розвитку малого підприємництва; 5) удосконалення функціональної та організаційної структури центральних і місцевих органів виконавчої влади в частині забезпечення розвитку і державної під- 
тримки малого підприємництва. Системне здійснення практичних заходів у цій сфері повинно забезпечити стабільну нормативноправову основу для ефективного розвитку підприємницької діяльності. Незмінність єдиних для всіх суб'єктів підприємницької діяльності відносин протягом тривалого часу є однією з найголовніших умов пожвавлення економічної ситуації в Україні.

Але головним нормативним актом, що регламентує основні засоби регулюючого впливу держави під час здійснення виробничої діяльності залишається Господарський кодекс (далі - ГК) України, зокрема ст. 12 ГК [12]. ГК чітко регламентує (ч. 2 ст. 12), що основними засобами регулюючого впливу держави на діяльність суб'єктів господарювання є: 1) державне замовлення; 2) ліцензування, патентування і квотування; 3) технічне регулювання; 4) застосування нормативів та лімітів; 5) регулювання цін і тарифів; 6) надання інвестиційних, податкових та інших пільг; 7) надання дотацій, компенсацій, цільових інновацій і субсидій. У цьому контексті державне замовлення (ст. 13) є засобом державного регулювання економіки шляхом формування на договірній (контрактній) основі складу й обсягів продукції (робіт, послуг), необхідної для пріоритетних державних потреб, розміщення державних контрактів на поставку (закупівлю) цієї продукції (виконання робіт, надання послуг) серед суб'єктів господарювання, незалежно від їхньої форми власності.

Ліцензування, патентування окремих видів господарської діяльності та квотування (ст. 14) є засобами державного регулювання у сфері господарювання, спрямованими на забезпечення єдиної державної політики в цій області, захист економічних і соціальних інтересів держави, суспільства й окремих споживачів. У сфері господарювання застосовуються технічні регламенти, стандарти, кодекси усталеної практики та технічні умови (ст. 15).

Відповідно до ст. 16 ГК України [12], держава може надавати дотації суб'єктам господарювання: на підтримку виробництва життєво важливих продуктів харчування, на виробництво життєво важливих лікарських препаратів і засобів реабілітації інвалідів, на імпортні закупівлі окремих товарів, послуги транспорту, що забезпечують соціально важливі перевезення, а також суб'єктам господарювання, що опинилися у критичній соціально-економічній або екологічній ситуації, 3 метою фінансування капітальних вкладень на рівні, необхідному для підтримання їхньої діяльності, на цілі технічного розвитку, що дають значний економічний ефект, а також в інших випадках, передбачених законом.

Крім того, держава може здійснювати компенсації або доплати сільськогосподарським товаровиробникам за сільськогосподарську продукцію, що реалізується ними державі.

Оподаткування як регулюючий вплив держави регламентується ч. 2 ст. 17 ГК [12]. 3 метою вирішення найважливіших економічних і соціальних завдань держави закони, якими регулюється оподаткування суб'єктів господарювання, повинні передбачати: 1) оптимальне поєднання фіскальної та стимулюючої функцій оподаткування; 2) стабільність (незмінність) протягом кількох років загальних правил оподаткування; 3) усунення подвійного оподаткування; 4) узгодженість із податковими системами інших країн.

Правовою формою регулюючого впливу держави на виробничу діяльність суб'єктів підприємництва насамперед є акт у вигляді цільової програми, дозволу, квоти, ліцензії, припису тощо, з яким зв'язуються передбачені законом наслідки. Щодо співвідношення форми та змісту правовий акт виступає правовою формою державного регулювання підприємницької діяльності. Правова реалізація використаних державою методів і способів впливу на виробничу діяльність суб'єктів підприємництва і являє собою правовий режим регулюючого впливу держави.

Цікаво те, що окремі види регулюючого впливу держави виконують функцію обмеження свободи виробничої діяльності суб'єктів підприємництва, зокрема ліцензування, технічне регулювання, ціноутворення тощо. Проте інші, як-от дотації, компенсації, податкові та митні пільги, є такими, що підтримують свободу підприємництва.

Необхідно зазначити, що методом державного регулювання виробничої діяльності $€$ також державний контроль і нагляд у сфері господарської діяльності. Так, відповідно до ст. 19 ГК [12], держава здійснює контроль і нагляд за господарською діяльністю суб'єктів господарювання в таких сферах, як: 1) збереження та витрачання коштів і матеріальних цінностей суб'єктами господарських відносин - за станом і достовірністю бухгалтерського обліку та звітності; 2) фінансові, кредитні відносини, валютне регулювання та податкові відносини - за додержанням суб'єктами господарювання кредитних зобов'язань перед державою і розрахункової дисципліни, додержанням вимог валютного законодавства, податкової дисципліни; 3) ціни та ціноутворення - 3 питань додержання суб'єктами господарювання дер- 
жавних цін на продукцію і послуги; 4) монополізм і конкуренція - щодо додержання антимонопольно-конкурентного законодавства; 5) земельні відносини - за використанням і охороною земель; водні відносини і лісове господарство - за використанням і охороною вод і лісів, відтворенням водних ресурсів і лісів; 6) виробництво і праця - за безпекою виробництва і праці, додержанням законодавства про працю; за пожежною, екологічною, санітарно-гігієнічною безпекою; за дотриманням норм і правил, якими встановлено обов'язкові вимоги щодо умов здійснення господарської діяльності; 7) споживання - за якістю і безпечністю продукції та послуг; 8) зовнішньоекономічна діяльність - щодо питань технологічної, економічної, екологічної та соціальної безпеки.

\section{Висновки}

Ефективний регулюючий вплив держави на виробничу діяльність суб'єктів підприємництва - одне з головних завдань держави на сучасному етапі. Його виконання потребує цілісної концепції про галузеву правову приналежність підприємницьких відносин, тобто про їхнє місце в системі права і законодавства, про оптимальне допустимі межі втручання держави у сферу регулювання виробничої діяльності підприємницьких відносин, а також про юридичні гарантії підприємництва та відповідальність у цій сфері.

Отже, можна зазначити основні чинники, що впливають на виробничу діяльність суб'єктів підприємництва: 1) ліцензування окремих видів господарської діяльності; 2) регулювання цін на окремі види продукції; 3) застосування системи податкових пільг; 4) використання політики прискорення амортизації; державна політика у сфері стандартизації та експертизи якості товарів, їхня відповідність міжнародним нормативним документам; 5) контроль за забезпеченням екологічності промислового виробництва; 6) комплекс антимонопольних заходів; 7) державна політика щодо залучення суб'єктів підприємницької діяльності до виконання державних і регіональних цільових комплексних програм.

\section{Список використаних джерел:}

1. Саніахметова Н.О. Підприємницьке право: Суб’єкти підприємництва. Кредитування. Оренда. Лізинг. Зовнішньоекономічна діяльність. Інвестиції. Антимонопольне законодавство. Захист від недобросовісної конкуренції. Реклама. Київ : A.C.K., 2001. 704 c.

2. Покатаєва О.В. Методи державного регулювання підприємницької діяльності. Економіка та держава. 2008. № 1. С. 89-91.

3. Про ліцензування видів господарської діяльності : Закон від 2 березня 2015 р. № 222-VIII. Відомості Верховної Ради України. 2015. № 23. Ст. 158.

4. Про ціни і ціноутворення : Закон України від 21 червня 2012 р. № 5007-VI. Відомості Верховної Ради Украӥни. 2013. № № 19-20. Ст. 190.

5. Про стандартизацію : Закон України від 5 червня 2014 р. № 1315-VII. Відомості Верховної Ради України. 2014. № 31. Ст. 1058.

6. Про зовнішньоекономічну діяльність : Закон України від 16 квітня 1991 р. № 959-XII. Відомості Верховної Ради Української Радянської Соціалістичної Республіки. 1991. № 29. Ст. 377.

7. Про захист економічної конкуренції : Закон України від 11 січня 2001 р. № 2210-III. Відомості Верховної Ради України. 2001. № 12. Ст. 6.

8. Кравцова Т.М. Правові форми державного регулювання у сфері підприємницької діяльності. Право України. 2003. № 12. С. 45-47.

9. Про державні цільові програми Закон України від 18 березня 2004 р. № 1621IV. Відомості Верховної Ради Украӥни. 2004. № 25. Ст. 352.

10.Про державне прогнозування та розроблення програм економічного і соціального розвитку України : Закон України від 23 березня 2000 р. № 1602-III. Відомості Верховної Ради України. 2000. № 25. Ст. 195.

11. Про Національну програму сприяння розвитку малого підприємництва в Україні. Заходи від 21 грудня 2000 р. № 2157-III. Відомості Верховної Ради Украӥни. 2001. № 7. Ст. 35.

12. Господарський кодекс України : Закон України від 16 січня 2003 р. № 436-IV. Офічійний вісник України. 2003. № 11. Ст. 462.

The peculiarities of state influence on industrial activity, its essence and forms are considered in the article. It is determined that economic law is the main and integral instrument of the regulatory influence of the state on production activity. Its role and importance in carrying out business activity is difficult to exaggerate, and issues related to the legal support of industrial activity have been and remain relevant today. The basic forms of regulatory influence of the state on the production activity of business entities are investigated. It is established that the regulatory influence of the state on the production activity of business entities is not limited to its support. The article also considers different approaches of scientists to differentiation of the means of regulatory influence of the state on industrial activity. On the basis of the analysis of legal acts regulating the implementation of state regulation of production activity, the main factors that influence the production activity of business entities are identified. Attention is drawn to the direction of state regulation of industrial activity, which concerns the state policy in the sphere of development of economic competition and restriction of monopoly in economic activity. It has been found that certain types of regulatory influence 
of the state serve as a restriction on the freedom of production of business entities, in particular, licensing, technical regulation, pricing, etc. However, others, such as subsidies, compensation, tax and customs benefits, are those that support freedom of enterprise. It is determined that one of the main tasks of the state at the present stage is the effective regulatory influence of the state on the production activity of business entities. And its implementation requires a holistic concept of the sectoral legal affiliation of business relations, that is, their place in the system of law and legislation, the optimal permissible limits of state intervention in the sphere of regulation of industrial activity of business relations, as well as legal guarantees of entrepreneurship and responsibility in this field. The article also outlines the main directions of state influence on production activity.

Key words: industrial activity, state regulation, commercial management, subjects of entrepreneurial activity, means of state regulation of commercial activity. 